\title{
Globalization of Migration Processes: on the Threshold of the New Migration Reality
}

\author{
Rakhmon Ulmasov ${ }^{1 *}$, Nurali Kurbanov ${ }^{2}$ \\ ${ }^{1}$ Faculty of Economics, Russian-Tajik (Slavonic) University, 30 M.Tursunzoda Str., Dushanbe, 734025, Tajikistan \\ ${ }^{2}$ Institute of Raw Material Industry Economics and Legislation of the Russian State Geological Prospecting University n. a. Sergo \\ Ordzhonikidze, 23 Miklukho-Maklaya Str., 117997, Russia
}

\begin{abstract}
In this paper, the authors address the global issues of migration on the threshold of a new migration reality. Migration is considered to be one of the most actively developing global issues at present as more and more people are crossing the border of their state for one reason or another. The authors determine a comprehensive analysis of issues, in particular, the accelerating processes of global warming, expanding social and political conflicts, economic crises, and migration collapse. All of these issues together indicate a very important idea: in all of its processes related to life, particularly in the area of migration, the world has reached the threshold of a New Reality. The authors have indicated with absolute accuracy those issues that need a most focused attention from national governments and international institutions. This way, there is an obvious fact that is paradoxical for many countries, especially the European ones: despite the complex socioeconomic situation, limited natural resources, rising unemployment, declining income, and increasing impelled migration, there is a sharp growth in population in the Republic of Tajikistan. Such demographic processes are a hallmark of predominantly poor and underdeveloped countries, where having many children is often the only factor of a family's survival as a social unit.
\end{abstract}

\section{Introduction}

For a quarter of a century, Tajikistan has witnessed all kinds of migration with various specifics and consequences. We are living in a complicated but interesting and responsible time of great changes on Earth that no one is likely to avoid. The accelerating processes of global warming, expanding social and political conflicts, economic crises, and migration collapse, all of these issues together indicate a very important idea: in all processes related to life, particularly in the area of migration, we have reached the threshold of a New Reality.

However, what do we observe today? We come to the conclusion that a more dangerous thing is an increase in xenophobia and common hatred:

1.Between migrants and native population.

2. Between the employed and those living on welfare.

3. Between adherents of different religions and cultures.

4. Between people who are markedly different from each other both outside and inside.

Time and again we receive proof of the inefficiency of the current measures to regulate the processes of migration and raise our migrants from their knees but continue to beat our heads against the wall with a tenacity that is worthy of a better use. Perhaps the time is right to realize that we are doing something wrong? 25 years have passed already:

- 25 years ago Europe did not have a common currency, the euro;

- 25 years ago there were no notable revolutions in the new economy, though the first signals were already evident;

- 25 years ago the world was completely different;

- 25 years ago there were no mobile phones;

- 25 years ago nobody thought that the United Kingdom would exit the EU;

- During these 25 years, Tajikistan has become a major player in Russia's labor market;

- Just a little earlier than these 25 years, all of these socalled "foreign workers" did not use to be foreign workers or migrants, they used to be residents of a single country [1]. They are ex-compatriots and thus adapt much easier than the Chinese or Vietnamese.

\subsection{Problem Statement}

Labor migration is not some kind of anomaly by itself. Both in human history and in the modern world, crossborder movement of workforce is a natural and quite habitual process even in developed countries. This way, in 2016, approximately $8.5 \%$ of Germany's able-bodied population was working outside their country, while, at the same time, over $13.6 \%$ of those employed in

Corresponding author: ulmasovr@gmail.com 
Germany proper were nationals of Western Asia [2]. A well-known example is that of Turkey that actively exports its labor resources, making them the foundation of its socioeconomic growth. We live in the era of globalization and migration unites the world. If in the 19 th century it would take 44 days to reach the USA, today a flight from Dushanbe to Chicago takes just 14 hours. The Internet and mobile phones are changing our lives. A developed transportation system and speeds previously unseen have made our world not that big. So, people started to move around with larger speeds and in larger numbers. Look at the statistics: the number of expats from Russia, Kazakhstan, Lithuania, Latvia, Armenia, and other countries is growing every year. "One hundred thousand people are leaving Ukraine every month..!!!" stated the Minister of Foreign Affairs of Ukraine, Pavlo Klimkin.

It is our belief that we will be able to improve the migration situation by cooperating with the leading countries. Such cooperation should be built pragmatically, without involving "sovereignty trading". After the migration collapse in Europe, common sense is starting to prevail in the consciousness of Europeans as well as Russians.

At this moment, there is an opportunity to demonstrate the steps forward that we have made and also imagine what will the coming 25 years be like. Why? Migration from the Republic of Tajikistan (RT) to the Russian Federation (RF) does not stop. Only in "January-March 235 thousand migrant workers from Tajikistan registered with the immigration authorities in the RF, and during the year this number amounted to 482,897 citizens of Tajikistan." Such is the data provided by the Ministry of Internal Affairs (MIA) of the RF. 234,540 out of all RT citizens registering with the RF authorities in the specified period are migrant workers. 4,777 citizens of Tajikistan indicated their purpose of travel as study and 540 citizens were checked in by the immigration authorities as tourists.

According to the MIA of Russia, 7,797 citizens of Tajikistan were granted Russian citizenship from January to March this year. In 2017, over 29 thousand natives of Tajikistan were granted Russian citizenship, which exceeds the numbers from 2012 almost three times [3].

There are fewer and fewer hidden mechanisms in the modern world. Our world is like a compass installed at a particular point in a particular interval of history. And we must also think about how we can improve the living standards, particularly those of immigrants, and decide what the immigrant of the nearest future be like. Where are we going to live and how? Will it be a society of the Internet, gigabytes, and ultra-broadband Internet access? Or something else?

\section{Results and Discussion}

\subsection{Ways of solving migration problems}

The existing problems of migrant workers are serious and, obviously, each of us sees their reasons in one's own way. However, due to the complex nature of the challenges that we are facing and the significance of the existing problems, we consider it fundamentally important that, at the current stage, we make all the efforts and try to resolve this problem together with Russia, looking into the future and indispensably remembering what unites us. If anything can be done together, we should and even must do it together with great relish!

In the 21 st century, all countries center their attention on the human capital, human values, and technological innovation, otherwise there will be neither migration nor development in the entire world.

"For 45 years we lived in the world order that was laid down in Yalta, then for the next 25 years, we lived in the world shaped by the Malta Summit. The painful lesson of the crisis in Ukraine is that the fundamental security issues in Europe have still not been resolved. The West lives in a world where time stands still. The myth of its victory in the Cold War can be considered the foundation of the existing world order. If we want to take the path of stability in Europe, we must break the old myths. The principles of European and global security must be revised, the stakes now are higher than ever." summarizes Richard Sakwa, a political analyst.

Can we influence the migration situation at all? We are out of time for doubt. Recently, people's interest towards developments and changes in the area of migration has become more and more pronounced. These topics are raised more and more often in the mass media and the Internet. Unfortunately, information often comes from incompetent sources and is thus contradictory and not trustworthy.

When it comes to migrants, we should always speak straightforwardly and trustingly both about our achievements and new opportunities, as well as the problems and complications that we face and the tasks that we have yet failed to resolve. This is not a motto, this is the content of our migration policy and the work we are currently undertaking to create the conditions for a migrant, find new partners, and explore new labor markets. Russian experts note the dynamic and "polyphonic" development of the migratory movement. The recipe to create favorable conditions for a migrant worker is actually known to everybody. First, it is necessary to achieve a high concentration of efforts in all directions both among the migrants and among the local community. And the second condition is the efficient management of all these efforts. If it is not there, then efforts by all institutions will be ineffectively squandered and the migrants will run every which way but loose. But, as the saying goes with doctors, when the recipe is known, it does not guarantee that the medicine will help. Knowing is one thing, doing it all right is another. And the latter requires exceptional perseverance and great willpower. Anyway, all secondary schools and higher education institutions should be aimed at training highlyqualified specialists that will become the new generation able to deal with complex multidimensional tasks in the era of the digital economy. Why schools and universities? University graduates should not work as laborers with their bachelor's or master's degrees. If they 
are highly-qualified specialists, they find work at home, and if they leave the country, they work within their area of training. This is so because they, meaning the youth, are ambitious, full of energy, open to the world, progressive, and ready to change and move forward. The last "ingredient" of the researchers' success is the efficient study of the processes of migration. Scientific research results do not appear immediately [5]. This is a rather long way.

After the British referendum, populists both in Europe and Russia will get a gust of inspiration in their sails and are highly likely to galvanize across all regions.

\subsection{Mechanisms of migrant worker protection}

In all these years, our migrants have been successfully passing a course of obstacles. If we make prompt efforts, the mechanisms for protecting migrant workers will, of course, work.

It is necessary to focus on resolving systemic problems within the agenda of the long-term development:

First. It is necessary to find a whole class of government managers that specialize in migration, who will be able to work in a flexible and modern way and will understand migrants' needs, their woes and suffering. One of the most important steps shall be launching a mechanism of continuous improvement of management personnel starting from jamoats all the way to the level of the Republic administration. Migration is not only the Ministry of Labor's work, it is a responsibility of all Ministries, authorities, and parliaments at all levels. In this regard, it is necessary to establish a center for training administrative personnel on the basis of the Research Institute of Labor, a center that will become a good site not only for advanced specialist training but also for exchanging experience, developing new ideas, and establishing horizontal relations between representatives of diasporas and regions of Russia.

Second. We consider it expedient to establish special headquarters in every district, city, and province. These will be project offices that will become a sort of contact points for migrants, provide them with all necessary information and propaganda materials and consultations. It is also necessary to organize Russian language courses and introduce the most efficient mechanisms of migrants' adaptation in a new environment. Here, a migrant should receive all the necessary financial, legal, and methodological assistance, including assistance in obtaining microloans.

Third. It is necessary to take inventory of the existing laws, programs, and concepts and analyze their performance. The migration problem of Tajikistan lies within ourselves because we are currently trying to find a point of balance in the migration space. The pivot to a migrant means the pivot to oneself, and solving one's immigrant problems must be done together with Russia above all. Our priority task today is managing to fit in the complex and rapidly changing world of migration.
Migration, regardless of its isolated negative features, has made a great contribution to the Russian and Tajik economies. Currently, Russia is quite selfsufficient in its present borders, but it needs workforce.

25 years of migration have shown that a Tajik migrant is capable of prolonged monotonous labor but lacks creativity very much. If we compare our migrants to others, for example, Armenians and Azerbaijanis, the distinctive features of our migrant appear to be a product of long historical development. They have shaped with time and became the result of a social compromise gained through suffering in a centuries-long bitter struggle. Tajik migrants did not attain these now unyielding values in a moment, but these values are what shaped our migrants' mentality and became a component of the predominant Russian culture.

It is obvious that every unseemly incident involving migrants affects the Tajik image. In this regard, everything must be constantly and comprehensively analyzed and evaluated. One cannot blame all migrant problems only on the global miscalculations that generally leave no one punished and no conclusions made afterwards.

The fault of our migrants is also obvious because, for a Tajik migrant, the goal (money) is more important than the process (continuous learning, progress). This indicates the lack of strategic thinking. The problem is much more serious than it seems at first glance, but let the professionals handle it. We hope that their high level of qualification will allow them to come to grips with it.

\subsection{Labor migration issues}

The issue of migration in Tajikistan, as well as in many other countries, is an interesting and still understudied phenomenon like a black hole or the Bermuda Triangle. At the moment, according to the results of the Russian census of 2010, Tajik population ranks 29th among all the ethnicities living in the RF and its growth rate is $67.73 \%$. Currently, there are more Tajiks in Russia then Kalmyks, Jews, Circassians, Koreans, etc. It is reasonable to think that, since the last census (between 2010 and 2016), the number of Tajiks has grown several times.

In the Republic of Tajikistan, as well as in other CIS countries, the most topical issue at the moment is the issue of labor migration and employment of the population. Tajikistan is traditionally considered a manpower-surplus country. This is conditioned by a high birth rate. From 2000 to 2013, the population of the Republic of Tajikistan increased by 2034.1 thousand people, i.e. from 6127.0 to 8161.1 thousand people. Tajikistan is a traditional leader in terms of birth rate among the CIS nations, surpassing the other high values demonstrated by Turkmenistan and Uzbekistan, to say nothing about other countries with a more European way of life. The rate of natural increase during the last 20-25 years maintains approximately the same level and comprises 223-24 persons per mille. The population keeps increasing and, according to the official forecasts, will reach 10 million by 2020 . For example, between 
1991 and 2014, the population of the Republic of Tajikistan grew by almost 3 million people [7]. This happened even in the conditions of the tremendous outmigration of (predominantly Russian-speaking) population and severe civilian casualties during the tragic events of the 90ies in the 20th century. Especially indicative is the growth of population in the inter-crisis period: from 2008 to 2014. In the term of 6 years, the population of Tajikistan increased by $1 \mathrm{mln} .100$ thousand people, that is, by more than $15 \%$.

In the RF, the demographic situation is highly unfavorable. Around $80 \%$ of the natural decrease rate in Russia is compensated by the influx of migrants. According to one of Russia's leading demographers, L.L. Rybakovskii, "the current mode of reproduction of population" combines "a European birth rate with an African mortality" [8].

A migrant is not just a profession, it is a way of life that not all people understand and accept. Today, millions of people around the world are involved in it. According to the forecast produced by the International Monetary Fund, around four million citizens from outside the EU are going to arrive in Europe in the period from 2015 to 2017 , that is approximately 1.33 million people per year. As the ex-Secretary General of the UN Ban Ki-moon noted in his Migrants Day address, 2015 will go down in history as a year of human suffering and migrant tragedies. "Over the past 12 months, more than 5,000 women, men and children lost their lives in search of protection and a better life. Tens of thousands more have been exploited and abused by human traffickers. And millions have been made into scapegoats and become the targets of xenophobic policies and alarmist rhetoric." [9] the address emphasized.

There are $6.5 \mathrm{mln}$. mixed marriages in Russia [10], including those involving migrants. Every year 12 thousand Tajiks start a family in Russia and there are many examples of happy mixed marriages, but we are not shown that. We are shown only the threat supposedly coming from the new arrivals. It is hard to disagree with the President of the "Migration 21st Century" Foundation, Vyacheslav Postavnin. "We do not see the main thing in migration, it is the two simplest principles that any migration policy should be built around: economic interests - migration should be oriented in a way that it will serve the development of the society, and humanism - these are people, this should be understood. Meanwhile, in our case, migrants are virtually halfslaves" [11].

How is modern Tajik migration different from the migration in the beginning of 2000 ?

First, migration from Tajikistan became rural. So, many of the problems that we observe in the relations between the native Russians and the migrants arise from the problems between the urban and rural populations.

Second, these migrants are less educated than they used to be. The more educated ones had long since left for Russia or other countries.

Third, these people are less proficient in the Russian language. It should be admitted: even under the Soviet rule, people in rural Tajikistan did not speak Russian as well as they did in the cities. Much less now. These factors result in a lot of tension that appears between the Russian locals and the arriving migrants.

\subsection{How can such situation be dealt with? Methods of solution}

First. Tajikistan, as well as other republics of the region, needs capable and renowned expert newsmakers as much as one needs air. It is necessary to carry out largescale social research and involve distinguished scientists who are able to shape a favorable public opinion both inside Tajikistan and outside it. Nothing is as frustrating as run-of-the-mill squabbles and amateurish attempts.

Second. The state should initiate the education of journalists that deal with the issue of migration. The absence of competent expert journalists who could cover the problems of migration can be a big setback. The journalism dealing with migration is related to modern politics and ideology since the role of the mass media is not only informing but also shaping the public opinion. It is reasonable to award state decorations of Tajikistan to Russian and other foreign journalists who work for the image of the Tajiks, for example, V. Soloviev, Maksim Shevchenko, Vladimir Zakhvatov, and others.

Third. More than 300 thousand Russian-speaking population left Tajikistan for the RF. Time goes on and the generation that has a positive experience of interethnic interaction in Tajikistan is passing away, while young people do not possess such experience. While the older generation is alive and well, it is necessary to make use of their experience, otherwise conflicts may arise tomorrow.

Fourth. Most of the conflicts with the local population occur in the areas of the migrants' compact settlement. By using German experience, we can develop a Russian national program for migrant adaptation.

The issue of migration stands out among the priority issues of the global politics together with geopolitics and geoeconomics, thus forming the three Gs: Geopolitics, Geoeconomics, and Geomigration.

\section{Conclusion}

Our suggestions on the threshold of a new migration reality:

First. The Russian side should be offered to carry out an amnesty for migrant administrative offenders.

Amnesty is always good. At the moment, a large number of fines is being issued that are not always reasonable due to the disproportion of the damage caused by one violation or another and the punishment imposed. This is why it is reasonable to discuss an "administrative" reform for migrant workers. An administrative amnesty is "larger than business", it is meant to be an effort that is likely to improve "the migration environment in general".

Second. To overcome the migration crisis, it is necessary to aspire not to what was there before, not to the "pre-sanction era", but to new milestones and a new 
place in the labor market. Introduce the world's best practices, cooperate, and go forward together.

Third. Tajikistan and other Central Asian republics need to focus not on what used to be but instead on what will come, the way it should be. The Russians (and this is almost a social consensus) are very much eager to establish order in the area of migration.

Fourth. Migrant recruitment policies must be changed fundamentally. Cronyism should be replaced with appreciating people that are honest, competent and well-prepared professionally, ready to selflessly serve the state, and have relevant work experience.

Nothing can be eternal and unchanging in the world. Especially now, when it is clear that the world is rapidly changing again, but not yet clear in what direction. Anyway, Tajikistan does not only face a similar challenge but the one that is three times harder.

\section{Acknowledgment}

The authors express their gratitude to the Russian-Tajik (Slavonic) University for financing the research under the University Development Program for 2018.

\section{References}

1. R.U. Ulmasov, What we should thank migrants for, Tajikistan and Contemporary World Journal. of SRC Under the President of the RT. (Dushanbe, 2012)

2. V. Supian, Centers of Attraction, Migration, 1 (1197), 57-66 (2016)

3. I.A. Avesta, Tj 3 May (2018)

4. Retrieved from: https://ria.ru/world/20150420/1059666430.html

5. V. Vasilenko, N. Nazarov, R. Ulmasov, Traps of Globalization. Noospheric Monitoring of the Security of Citizens of Sovereign UN States Within the Earth Dome (2017)

6. Outcomes of the Russian Census of 2010, Retrieved from: http://www.kroupnov.ru/5/232_1.shtml

7. Statistical indicators of the social sector of the Republic of Tajikistan. Statistical Agency under President of the Republic of Tajikistan. The situation in the labor market of the Republic of Tajikistan (Report prepared on the basis of studying the workforce, carried out from 20 July to 20 August 2016) Project "Implementation of the National Strategy for the Development of Statistics Project" ECASTAT No. TF017852 (Dushanbe 2017)

8. L. L. Rybakovskii, Functions and consequences of migration processes, Sotsiologicheskie Issledovaniia, 10, 56-63 (2017)

9. http://www.fergananews.com/news.php?id=24274

10. E.Soroko, Ethnically mixed married couples in the Russian Federation, Demographic Review (2014)

11. Retrieved from: http://migrant.ru/my-i-oni-omigrantax-yazyke-vrazhdy-i-agressivnoj-

mentalnosti/ 